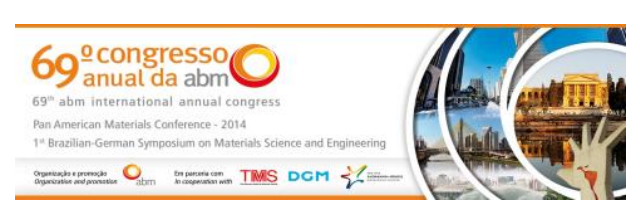

Tema: Surface Engineering

\title{
INFLUENCE OF MICROMILLING ON THE SURFACE INTEGRITY OF SUPER DUPLEX STAINLESS STEEL*
}

\author{
Adriane Lopes Mougo ${ }^{1}$ \\ Fábio de Oliveira Campos ${ }^{1}$ \\ Anna Carla Araujo
}

\begin{abstract}
Super duplex stainless steel presents a biphasic structure composed by ferrite and austenite with different characteristics and properties. In the micromilling process the cutting edge radius has similar dimensions to the grain size. The biphasic structure found in this material could influence on the cutting tool life and the surface integrity of the workpiece. Due to its low machinability, caused by high hardening level and low thermal conductivity, the process can produce built-up edge and high surface roughness $\left(R_{a}\right)$. In this work it is performed an experimental study of the micromilling of super duplex UNS 32750 and the influence of the cutting speed $\left(V_{c}\right)$ and feed per tooth $\left(f_{z}\right)$ on the surface integrity and tool wear. The design of experiments considered two levels and three replicates. Results indicate the increase of roughness for bigger feed per tooth, small influence of the cutting parameters on the burr formation. The tool presented flank wear after the experiments.
\end{abstract}

Keywords: Micromilling; Super duplex; Surface integrity; Tool wear.

1 Doutoranda em Engenharia Mecânica, Laboratório de Pesquisa em Usinagem CEFCON, Departamento de Engenharia Mecânica, COPPE, UFRJ, Rio de Janeiro, RJ, Brasil.

2 Enga Mecânica. D.Sc., Laboratório de Pesquisa em Usinagem CEFCON, Departamento de Engenharia Mecânica, COPPE, UFRJ, Rio de Janeiro, RJ, Brasil.

\footnotetext{
* Contribuição técnica ao $69^{\circ}$ Congresso Anual da ABM - Internacional e ao 14ํㅡㄹ ENEMET - Encontro Nacional de Estudantes de Engenharia Metalúrgica, de Materiais e de Minas, 21 a 25 de julho de 2014, São Paulo, SP, Brasil.
} 


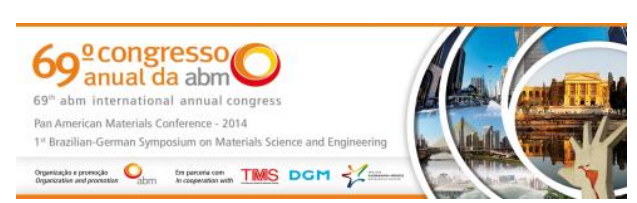

\section{INTRODUCTION}

One of the main concerns related to the increase the quality of microcomponents is reducing the costs simultaneously. The part dimensions, which are constantly getting smaller, and geometric complexities play an important role on micromanufacturing. Among the different manufacturing processes, micromilling is a priority research theme as it presents high material removal rate, great surface quality and it enables the manufacturing of a big quantity of parts using different kinds of materials as shown by Schmidt and Tritschler [1]. Arai [2] asserts that the most problematical aspects of the product fabricated by micromilling are burrs and surface roughness, because post processing of microcomponents is very complex and would represent high costs. Therefore, it is recommended that the process used for micro manufacturing deliver a finished workpiece.

The mechanism of cutting in micromilling should consider "size effect", as claimed by Aramcharoen and Mativenga [3]. Bao and Tansel [4] showed that feed per tooth to tool radius ratio has to be higher than in conventional milling to keep productivity at a reasonable level. Due to the small size of the micro tools, which have a diameter smaller than $2 \mathrm{~mm}$, it is very difficult to notice the damage in the cutting edges. Besides, an inappropriate selection of the cutting conditions can cause unexpectedly tool breakage and affect the surface integrity of the workpiece. In the conventional cutting process, the cutting edge passes by volumes composed by several grains, so the isolate contact with specific hardened particles or phases does not occur. But during cutting in micro scale, shown in Figure 1, the cutting edge encounter isolate and different grains which are a lot of times hardened by two-dimensional crystalline defects.
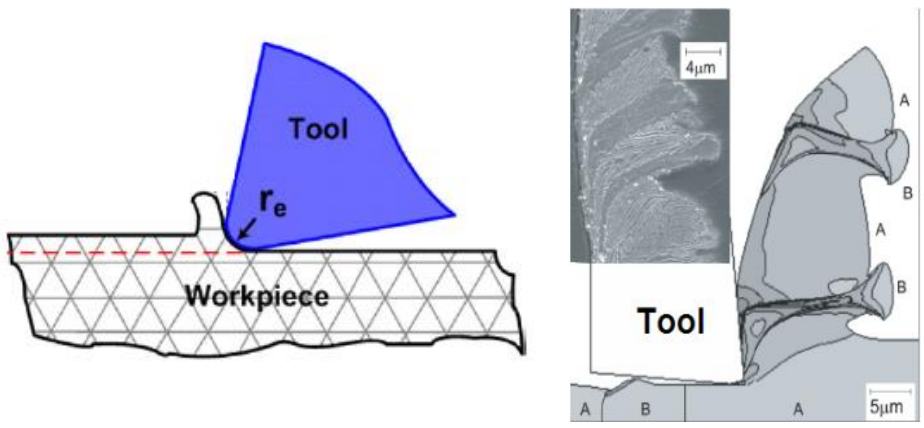

Figure 1. Cutting edge in micro-scale cutting and microchip formation from the heterogeneous material, adapted from Aramcharoen and Mativenga [3]; Simoneau and Elbestawi [5].

Weule et al. [6] observed that roughness increases at low cutting speed for soft materials and hardly changes for hard materials. Takács et al. [7], studying the micromilling for different metallic materials, observed that low feed per tooth causes higher roughness. Likewise, Jin et al. [8] studied the effect of cutting parameters on the micromilling of AISI D2 steel and the results showed that feed per tooth presented higher influence on the surface topography. Aramcharoen and Mativenga [3] studied the influence of size effect on the micromilling of tool steel H13. The results showed that the size of the burr decreased with the raise of the feed per tooth values and that the cutting tool wear influenced negatively the surface finishing and the burr size. Biermann and Steiner [9] studied the formation of microburrs on the micromilling of $\mathrm{X} 5 \mathrm{CrNi18-10}$ steel, varying the cutting speed and the feed per

\footnotetext{
* Contribuição técnica ao $69^{\circ}$ Congresso Anual da ABM - Internacional e ao 14ํㅡㄹ ENEMET - Encontro Nacional de Estudantes de Engenharia Metalúrgica, de Materiais e de Minas, 21 a 25 de julho de 2014, São Paulo, SP, Brasil.
} 


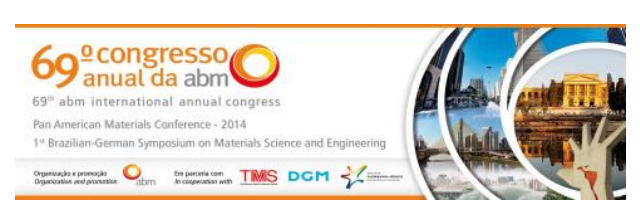

tooth. Results showed that the increase of cutting speed and feed per tooth produces giher top burr height. This is because of the increase on the stain rate and the failure of higher material removal rate.

Duplex and super duplex steels are between the most studied materials in machining and micromachining process. Bordinassi et al. [10] analyzed the surface integrity of duplex stainless steel ASTM A890-Gr6A after turning with different tools, materials, feed, depth and cutting speed. The best results for the surface integrity were found with lower feed, lower cutting speed and bigger depth of cut. Fonseca et al. [11] verified that in milling of super duplex stainless steel UNS S 32750, low cutting speed and high speed steel tool improve surface integrity.

Super duplex steels have a two-phase structure containing ferrite and austenite in almost equal proportion and the most common problem of this material is the cold hardening process experienced by the metal structure after plastic deformation, which can occur during the machining process. The increase in the surface hardness can cause an increase on the shearing forces necessary to remove the chip in micromachining process, influencing the quality of the workpiece and the tool wear.

So, this work has the objective to present an experimental study of the micromilling of super duplex stainless steel UNS S 32750 and to verify the influence of the cutting speed and feed per tooth on the average roughness, on the burr formation and tool wear.

\section{EXPERIMENTAL SETUP}

The materials and methods used to analyze the influence of the micromilling on the surface integrity of super duplex stainless steel are detailed in this section.

\subsection{Material and Experimental Apparatus}

The super duplex stainless steel UNS S 32750 workpiece has been prepared for flatness before the channels machining. The dimension of the flat surface is $40 \mathrm{~mm} x$ $20 \mathrm{~mm}$, as presented in Figure 2 (a). The heterogeneous microstructure can be seen in Figure 2 (b). For the preparation of this sample, sandpapers of 220 to 600 mesh were used to polish the surface with diamond paste of $3 \mu \mathrm{m}$ and $1 \mu \mathrm{m}$, respectively, and it was performed an electrolytic attack, with reagent composed of $20 \mathrm{~g} \mathrm{of} \mathrm{NaOH}$ and $100 \mathrm{ml}$ of distilled water, by the immersion method during approximately $2 \mathrm{~min}$.

After the metallographic preparation, the images were analyzed in the Image-Pro Plus software in order to quantify the volumetric fraction of the ferrite, dark grains in Figure1b, (52\%) and austenite (48\%) phases.

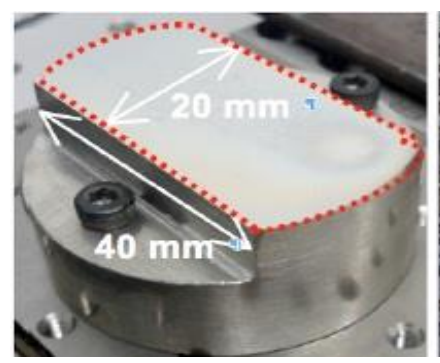

(a) Workpiece material

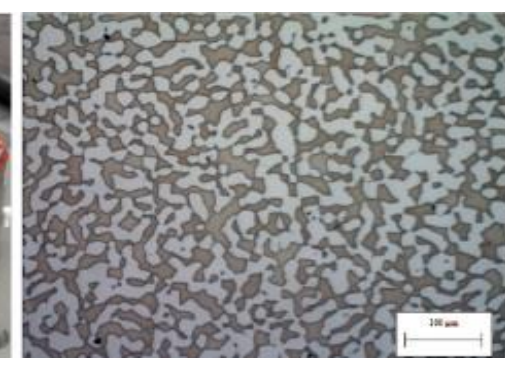

(b) Microstructure

Figure 2. Super duplex stainless steel (UNS S 32750)

\footnotetext{
* Contribuição técnica ao $69^{\circ}$ Congresso Anual da ABM - Internacional e ao 14ํㅡㄹ ENEMET - Encontro Nacional de Estudantes de Engenharia Metalúrgica, de Materiais e de Minas, 21 a 25 de julho de 2014, São Paulo, SP, Brasil.
} 


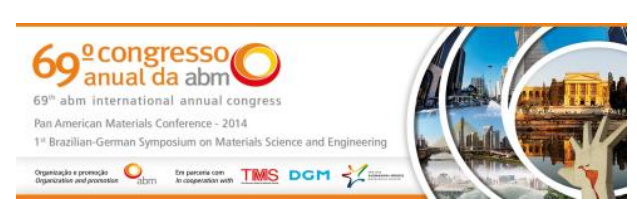

A Tungsten Carbide-Cobalt micromilling tool with $0.8 \mathrm{~mm}$ diameter and two flutes was used, as shown in Figure 3. The cutting length is coated with Titanium aluminum nitride (TiAIN-F) with thin particles, as noted in EDS analysis (Figure 4). This tool is recommended for machining steels harder than $48 \mathrm{HRC}$.

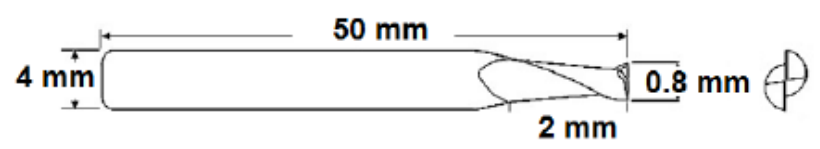

Figure 3. Dimensions of the micro milling tool.

A micro hardness test on the workpiece surface, as new, was developed applying $1 \mathrm{Kg}$ load for approximately $30 \mathrm{~s}$. The micro hardness average found was $346 \mathrm{HV}$, that is, $35 \mathrm{HRC}$, according to the conversion table.

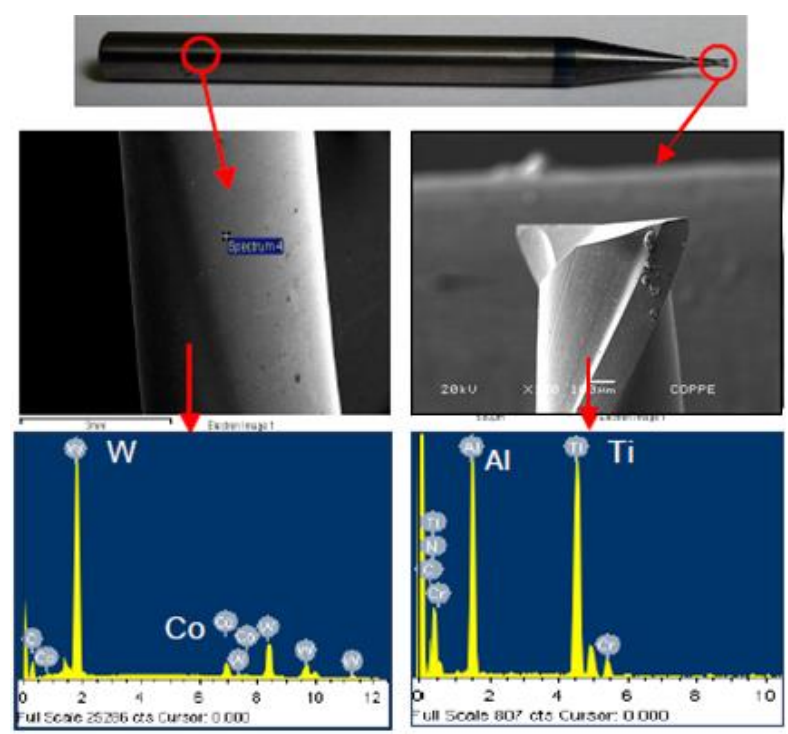

Figure 4. SEM Microscopy and EDS of Micro milling tool.

The CNC Mini Mill/GX micro machine tool was used on the experiments. The machine uses NSK 60k RPM precision spindle with 3-axis controller. Its standard resolution is $0.78125 \mu \mathrm{m}$ using dual linear ball bearing slides on each axis, sealed for the table mechanism (THK linear slides - RSR15 series, cagedball technology). The drive mechanism THK Ball Screw actuator - preloaded and sealed, achieves low torque fluctuation and no backlash.

\subsection{Experimental Procedure}

Before the actual micromilling experiments started, a surface of $33 \times 20 \mathrm{~mm}$, the work area, was faced on the workpiece using a $3 \mathrm{~mm}$ milling tool and the perpendicularity of the milling axis regarding the milling surface was checked with a dial indicator. It was used $50 \mathrm{~m} / \mathrm{min}$ as cutting velocity, feed rate of $100 \mathrm{~mm} / \mathrm{min}$ and $0.1 \mathrm{~mm}$ depth of cut. The face milling operation is important because it ensures that the micromilling experiments would be performed on a flat surface. If the surface to be machined was not flat, the axial depth of cut could vary during the cutting process and the results would not be valid.

\footnotetext{
* Contribuição técnica ao $69^{\circ}$ Congresso Anual da ABM - Internacional e ao 14ํㅡㄹ ENEMET - Encontro Nacional de Estudantes de Engenharia Metalúrgica, de Materiais e de Minas, 21 a 25 de julho de 2014, São Paulo, SP, Brasil.
} 


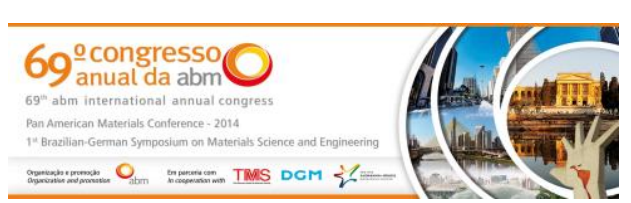

The experiments were planned in order to analyze the influence of two factors, with two levels each, on the roughness, burr formation and tool wear. The factors chosen were the feed per tooth and the cutting velocity with three replicates for each experiment. It was used clockwise spindle speed and cutting fluid (Microcut 510F Quaker Chemical). Table 1 resumes the cutting parameters used on the experiments.

Table 1. Cutting Data

\begin{tabular}{ll}
\hline Data & Values \\
\hline Spindle speed $(\mathrm{n})$ & $12000 \mathrm{rpm}$ and $2000 \mathrm{rpm}$ \\
\hline Feed per tooth & $7 \mu \mathrm{m} /$ tooth and $10 \mu \mathrm{m} /$ tooth \\
\hline Depth of cut & $100 \mu \mathrm{m}$ \\
\hline Tool & Tungsten carbide $\left(\mathrm{a}_{\mathrm{e}}=\mathrm{d}=0.8 \mathrm{~mm}\right)$ \\
\hline Workpiece & Super duplex UNS S 32750 \\
\hline
\end{tabular}

The Table 2 presents the cutting parameters used in each experiment and 3 replicates were executed for each of them. The order of the tests was planned in a way to ensure the randomization. This way, 12 channels were milled with approximately $5 \mathrm{~mm}$ length and spaced out of $1.5 \mathrm{~mm}$, as Figure 5 shows. The force components presented ( $F_{x}$ and $F_{y}$ ) represent the components on the plane normal to the spindle axis.

Table 2. Cutting Data

\begin{tabular}{cccc}
\hline Exp. & Tests & $\mathrm{fz}(\mathrm{mm} /$ tooth $)$ & $\mathrm{n}(\mathrm{rpm})$ \\
\hline 1 & 5,6 and 11 & 0.007 & 20000 \\
\hline 2 & 1,3 and 8 & 0.007 & 12000 \\
\hline 3 & 4,7 and 9 & 0.01 & 2000 \\
\hline 4 & 2,10 and 12 & 0.01 & 12000 \\
\hline
\end{tabular}

In order to measure the roughness and the burr height, it was used the Form Talysurf Intra, from Taylor Hobson, series 0120, capable of high precision measures of roughness, waves, shapes and profiles. It has transversal length of $0.1 \mathrm{~mm}-50 \mathrm{~mm}$ and maximum speed of $10 \mathrm{~mm} / \mathrm{s}$. Standard Inductive Gauge, stylus code 112/2009, stylus type $2 \mu \mathrm{m}$ Standard $60 \mathrm{~mm}$ with $90^{\circ}$ conisphere diamond was used, as presented in Figure 6(a). For the surface analysis it was used the Software Ultra Surface Finish V5.

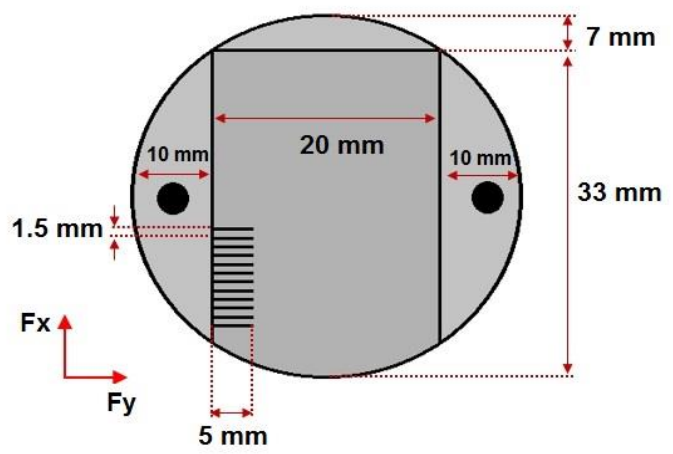

Figure 5. Workpiece, channel dimensions and force components.

The measure of roughness was performed in two stages: first on the transversal direction of the channels, where the directions 1,2 and 3 correspond respectivaly to

* Contribuição técnica ao $69^{\circ}$ Congresso Anual da ABM - Internacional e ao 14ํㅡㄹ ENEMET - Encontro Nacional de Estudantes de Engenharia Metalúrgica, de Materiais e de Minas, 21 a 25 de julho de 2014, São Paulo, SP, Brasil. 


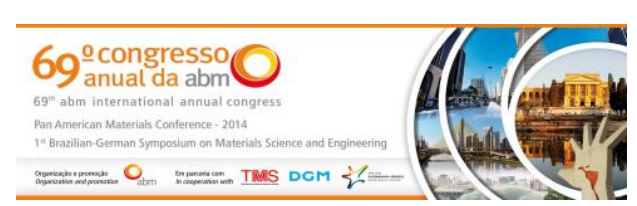

the start, middle and end of the cutting process; then on the longitudinal direction of the channels, that is, in the same direction of the feed of the tool, as shown in the Figure 6(b).

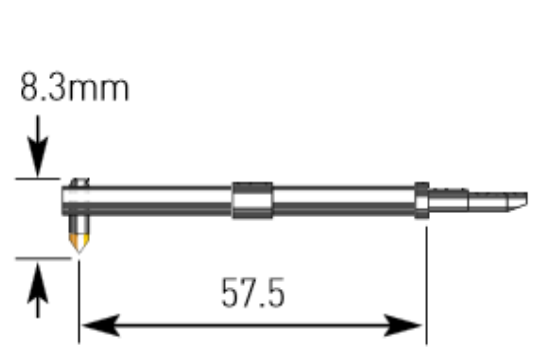

(a) Standard Inductive Gauge (112/2009)

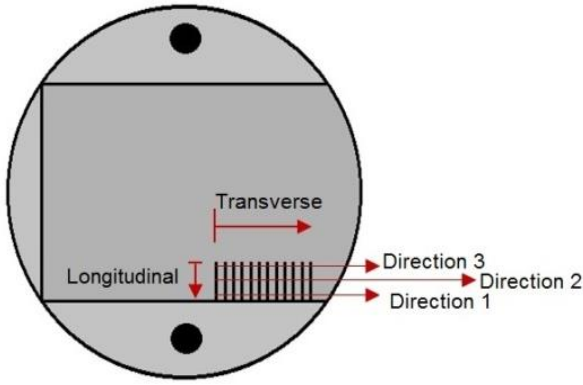

(b) Roughness measure

Figure 6. Method of measuring roughness and burr height.

Measures in transversal direction allowed also the acquisition of the dimension of the channels and burr height on the start (hs) and end (he) of the cutting process, as shown in Figure 7. So, it was possible to compute the average of the hs and he values for the three replicates of all four experiments and to verify a possible influence of the cutting parameters on burr formation. The roughness and burr height values obtained from the measure on the transversal direction will be always presented as the average of the three replicates.

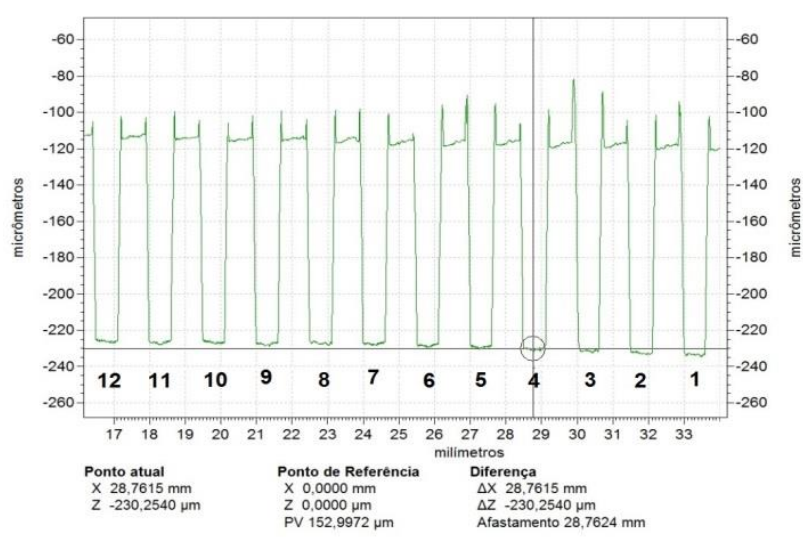

(a) 12 micromilled channels

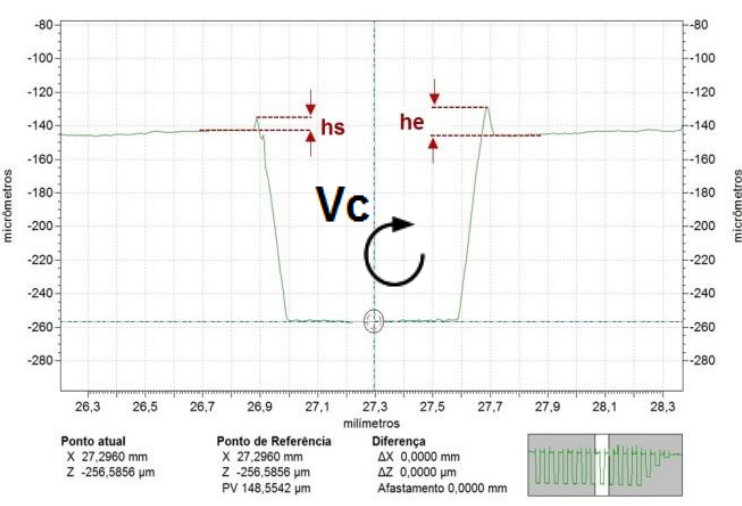

(b) Measure of burr height in channels 5 .

Figure 7. Measure of burr height.

\section{RESULTS ANS DISCUSSIONS}

In this section, the roughness results in both directions are presented, as well as the top burr height values for all experiments. Tool wear is also presented.

\subsection{Surface Roughness}

Figure 8 presents an example of the longitudinal direction of measure, indicating the displacement of $3 \mathrm{~mm}$ along the channel and of the roughness profile obtained. It was performed only one measure for each channel and, then, the mean of the replicates were computed.

\footnotetext{
* Contribuição técnica ao 69ำ Congresso Anual da ABM - Internacional e ao 14ํㅡㄹ ENEMET - Encontro Nacional de Estudantes de Engenharia Metalúrgica, de Materiais e de Minas, 21 a 25 de julho de 2014, São Paulo, SP, Brasil.
} 

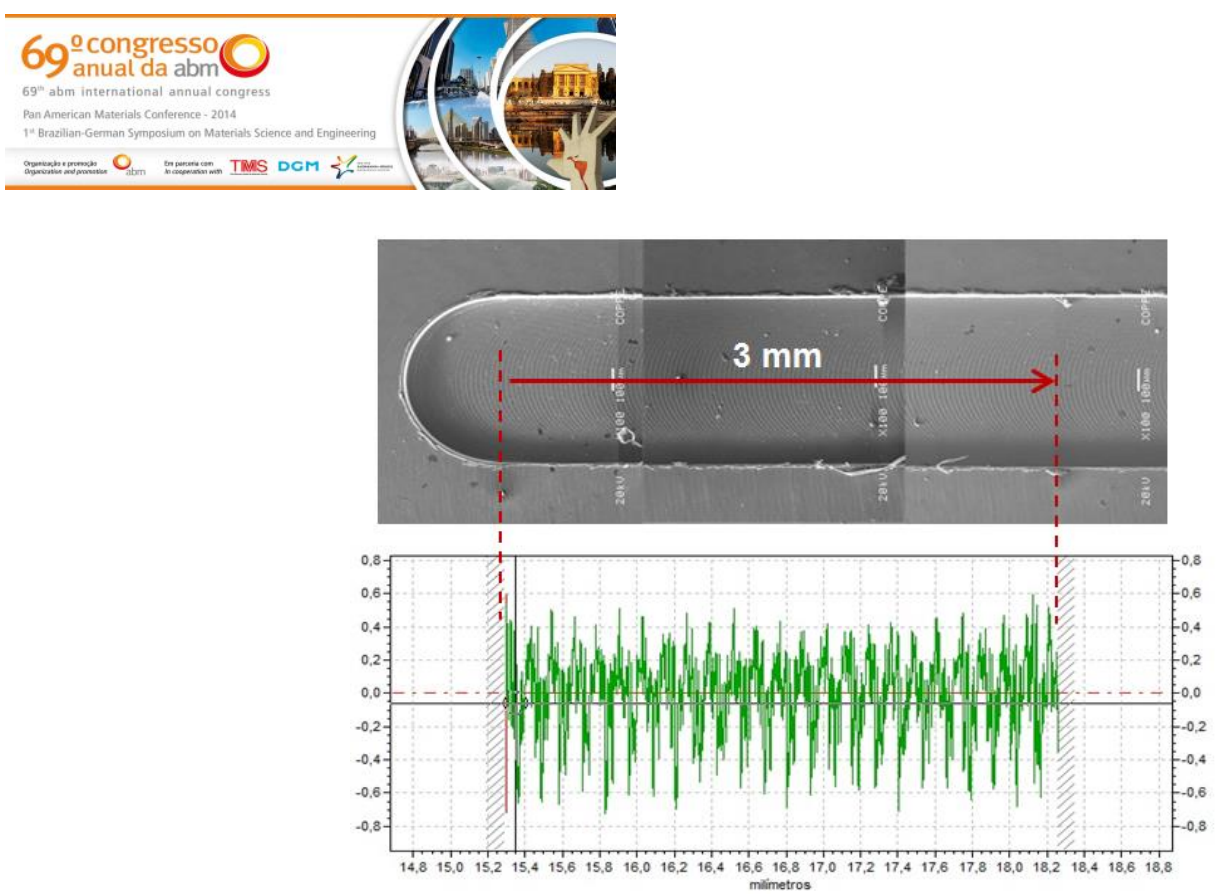

Figure 8. Longitudinal roughness measure.

Figure 9 presents the profile of the micromilled channel, where $\Delta \mathrm{x}_{1}$ and $\Delta \mathrm{x}_{2}$ correspond to the width which was not measured because of the limitation of the standard inductive gauge which has an angle of $90^{\circ}$, and $\Delta \mathrm{x}_{3}$ corresponds to the useful width of the channel. The sum of $\Delta \mathrm{x}_{1}, \Delta \mathrm{x}_{2}$ and $\Delta \mathrm{x}_{3}$ is, approximately, equal to the cutting tool diameter $(\mathrm{d}=0.8 \mathrm{~mm})$. Therefore, the useful width for the measure of $R_{a}$ values is approximately $0.6 \mathrm{~mm}$.

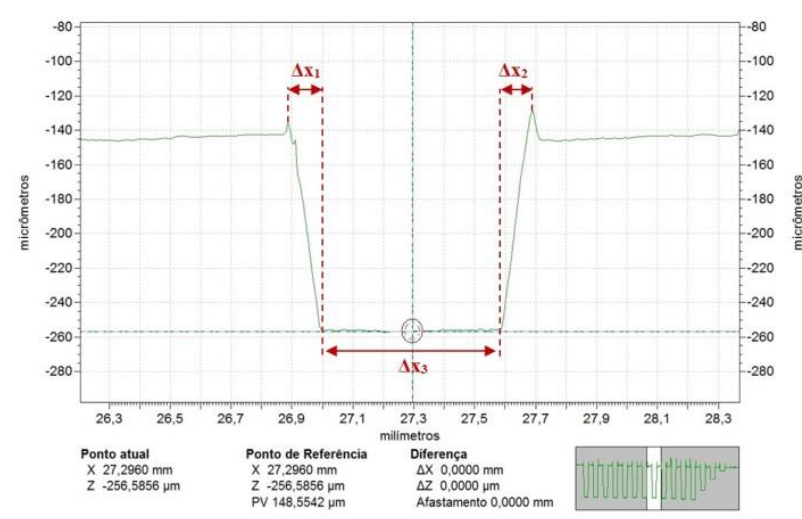

(a) Channels transversal dimension

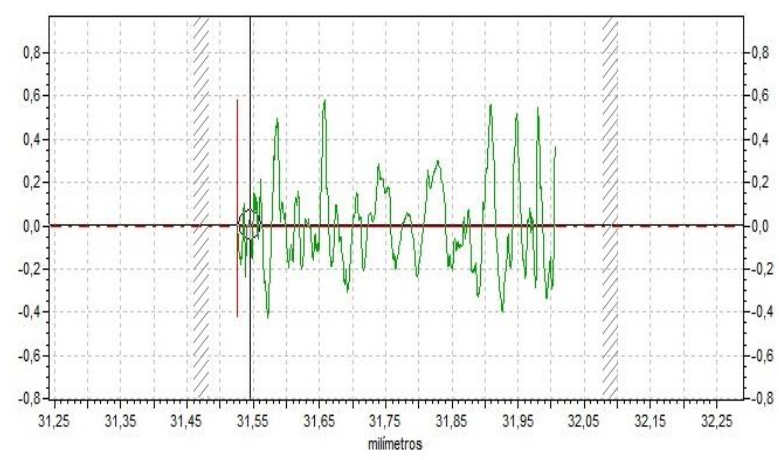

(b) Roughness profile in $\Delta \mathrm{x}_{3}$

Figure 9. Transversal roughness measure.

Three measures were performed in transversal direction (see Figure 6) and the values obtained were used to compute the averaged roughness of each channel. Table 3 and Figure 10 present the longitudinal and transversal average roughness for the replicates of all four experiments.

Table 3. Longitudinal and transverse roughness.

\begin{tabular}{c|c|c|c|c|c}
\hline \multicolumn{6}{c}{$\mathrm{Ra}(\mu \mathrm{m})$} \\
\hline Experiment & Tests & $\mathrm{fz}(\mathrm{mm} /$ tooth $)$ & $\mathrm{n}(\mathrm{rpm})$ & Longitudinal & Transverse \\
\hline 1 & 5,6 and 11 & 0.007 & 20000 & 0.1730 & 0.1527 \\
\hline 2 & 1,3 and 8 & 0.007 & 12000 & 0.2001 & 0.1289 \\
\hline 3 & 4,7 and 9 & 0.01 & 2000 & 0.2757 & 0.2074 \\
\hline 4 & 2,10 and 12 & 0.01 & 12000 & 0.2705 & 0.1901 \\
\hline
\end{tabular}

\footnotetext{
* Contribuição técnica ao $69^{\circ}$ Congresso Anual da ABM - Internacional e ao 14ํㅡㄹ ENEMET - Encontro Nacional de Estudantes de Engenharia Metalúrgica, de Materiais e de Minas, 21 a 25 de julho de 2014, São Paulo, SP, Brasil.
} 

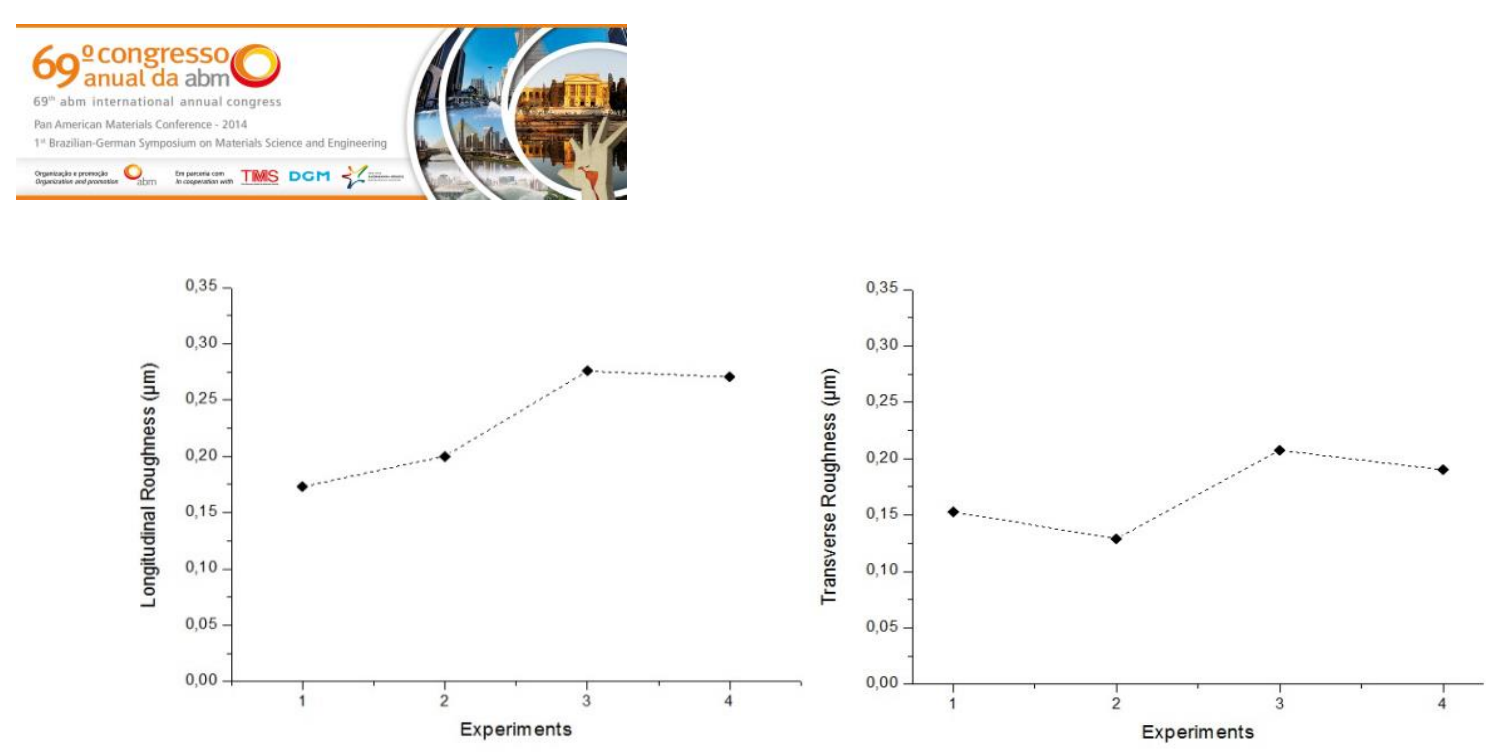

Figure 10. Longitudinal and transverse roughness.

Experiments 1 and 2 (Figure 10) with lower feed per tooth values, presented lower roughness values. This is not expected considering of what was shown in works by Takács et al. [7] and Jin et al. [8].

Aramcharoen and Mativenga [3] showed that the relation between the undeformed chip thickness and the cutting tool edge radius $\left(r_{e}\right)$ is a parabolic function, as in Figure 11(a). When $r_{e}>f_{z}$, roughness decreases with the raise of feed per tooth. This is due to the reduced presence of the ploughing effect for higher feed per tooth, resulting in less elastic recovery of the workpiece material, Figure 11(b). When $r_{e}<f_{z}$, roughness increases with the raise of feed, because cutting mechanisms actuate similarly to conventional machining. Therefore, as $r_{e}=2.5 \mu \mathrm{m}$ and $f_{z}=7$ and 10 $\mu \mathrm{m} /$ tooth $\left(r_{e}<f_{z}\right)$, roughness tends to increase with the raise of feed per tooth.

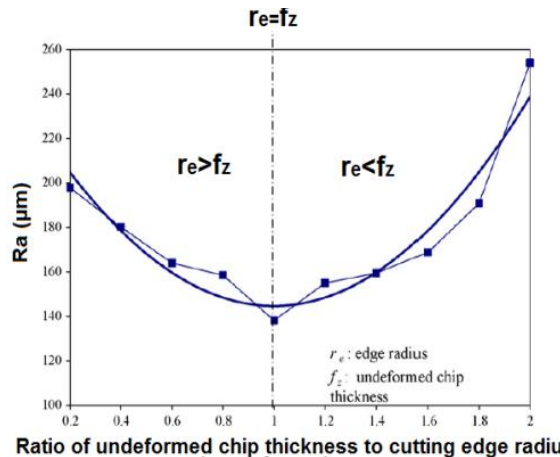

(a) Surface Roughness, Aramcharoen and Mativenga [3].

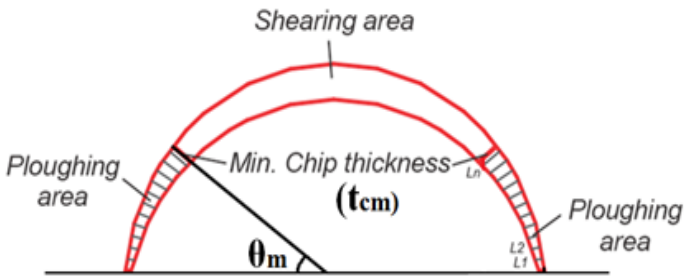

(b) Shearing and ploughing areas when $a e=2 R=D$, adapted from Bayesteh et al. [12]

Figure 11. Analysis of the variation of the roughness regarding of $r_{e}$ and $f_{z}$.

In order to analyze the influence of the factors, feed per tooth and cutting speed, in the surface roughness in both directions, longitudinal and transversal, it was made a Two-Way Analysis of Variance (ANOVA). It was used the following data configuration:

\begin{tabular}{|l|l|l|l|}
\cline { 2 - 4 } \multicolumn{1}{c|}{} & Parameter & -1 & +1 \\
\hline P1 & Cutting Speed & 12000 & 20000 \\
\hline P2 & Feed & 0.07 & 0.1 \\
\hline
\end{tabular}

First, an ANOVA for the longitudinal roughness was executed. The hypotheses tested for each parameter were:

* Contribuição técnica ao 69 Congresso Anual da ABM - Internacional e ao 14ํㅡㄹ ENEMET - Encontro Nacional de Estudantes de Engenharia Metalúrgica, de Materiais e de Minas, 21 a 25 de julho de 2014, São Paulo, SP, Brasil. 


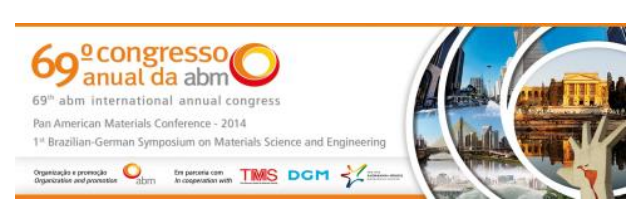

- HO (Null Hypothesis) - the longitudinal roughness does not vary with the parameter;

- $\mathrm{H} 1$ (Alternative Hypothesis) - the longitudinal roughness varies with the parameter.

The results are shown in Table 5. Using a significance level $\alpha$ of 0.05 , a critical value $\mathrm{F}$ of 5.32 is found. From Table 4, it can be seen that feed per tooth has a significant influence on longitudinal roughness values, as $F>F_{\text {critical }}$.

Table 4. ANOVA Longitudinal roughness.

\begin{tabular}{l|c|c|c|c|c}
\hline Source & SS & Df & MS & F & Prob $>$ F \\
\hline Spindle speed & 0.00037 & 1 & 0.00037 & 0.64 & 0.4455 \\
\hline Feed per tooth & 0.02241 & 1 & 0.02241 & 38.8 & 0.0003 \\
\hline Interaction & 0.0008 & 1 & 0.0008 & 1.38 & 0.2739 \\
\hline Error & 0.00462 & 8 & 0.00058 & & \\
\cline { 1 - 4 } Total & 0.0282 & 11 & \multicolumn{1}{|l}{} &
\end{tabular}

Table 5 shows the results for the ANOVA executed for the transversal roughness. It shows that both factors have influence in the transversal roughness values, considering a significance level of 0.05 . Moreover, it can be seen that the influence of the feed per tooth is greater than of the cutting velocity.

Table 5. ANOVA Transverse roughness.

\begin{tabular}{l|c|c|c|c|c}
\hline Source & SS & Df & MS & F & Prob>F \\
\hline Spindle speed & 0.00126 & 1 & 0.00126 & 6.55 & 0.0337 \\
\hline Feed per tooth & 0.01008 & 1 & 0.01008 & 52.2 & 0.0001 \\
\hline Interaction & 0.00003 & 1 & 0.00003 & 0.16 & 0.7004 \\
\cline { 1 - 4 } Error & 0.00154 & 8 & 0.00019 & & \\
\cline { 1 - 4 } Total & 0.01292 & 11 & \multicolumn{4}{|c}{}
\end{tabular}

\subsection{Burr Formation}

The control of the burr formation through an adequate selection of the cutting parameters in micromachining shows high relevance, as they will influence on the tool wear and on the surface integrity of the workpiece. Its formation depends on the minimum chip thickness, the cutting tool edge radius and the part material, Moreira [13]. Figure 12 shows the types of burrs usually formed in micromilling process, Hashimura et al. [14] and the image of the top and side views of the replicate 1 of the first experiment.

\footnotetext{
* Contribuição técnica ao $69^{\circ}$ Congresso Anual da ABM - Internacional e ao 14ํㅡㄹ ENEMET - Encontro Nacional de Estudantes de Engenharia Metalúrgica, de Materiais e de Minas, 21 a 25 de julho de 2014, São Paulo, SP, Brasil.
} 


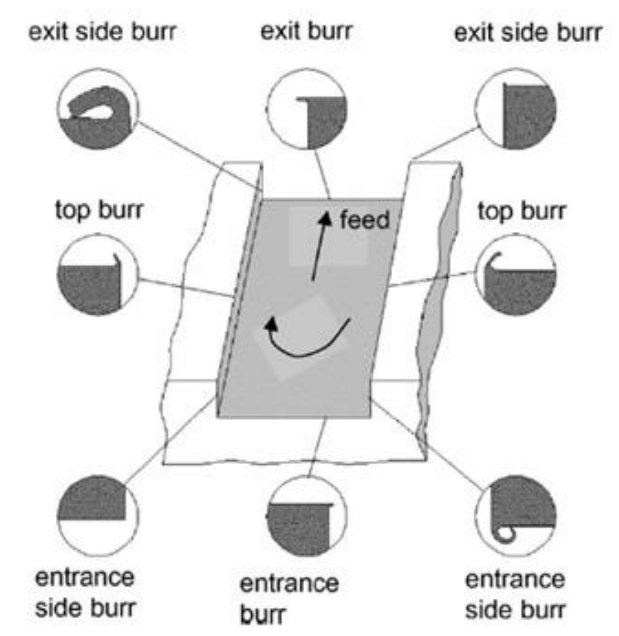

(a) Types of milling burr, Hashimura et al. [14]
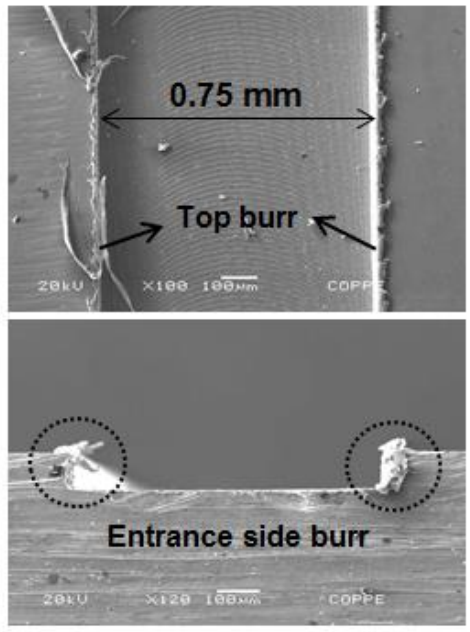

(b) Top and side view from SEM

Table 6 shows the mean of the top burr height and Figure 13 presents the image from SEM for a replicate of each channel obtained in the direction 2 (see Figure 5b). So, it is possible to observe that for experiments 1 and 2, obtained with lower feed per tooth, the occurrence of top burr was higher. At lower feed per tooth, the rubbing and compression of the material take place instead of cutting and this generates more burrs, Aramcharoen and Mativenga [3].

Table 6. Top burr heigth.

\begin{tabular}{c|c|c|c|c}
\hline Experiment & Tests & $\mathrm{fz}(\mathrm{mm} / \mathrm{tooth})$ & $\mathrm{n}(\mathrm{rpm})$ & Average \\
\hline 1 & 5,6 and 11 & 0.007 & 20000 & 16,2075 \\
\hline 2 & 1,3 and 8 & 0.007 & 12000 & 20,0292 \\
\hline 3 & 4,7 and 9 & 0.01 & 2000 & 14,9306 \\
\hline 4 & 2,10 and 12 & 0.01 & 12000 & 12,2839 \\
\hline
\end{tabular}

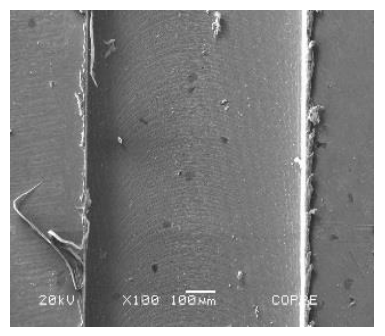

(a) Exp. 1

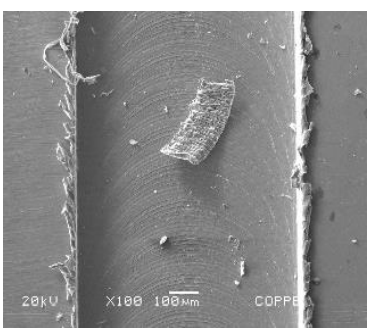

(b) Exp. 2

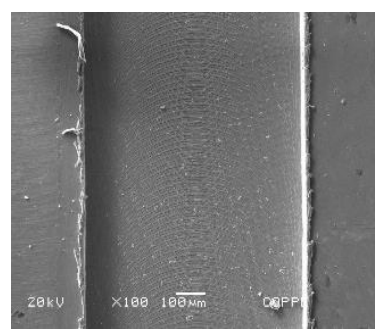

(c) Exp. 3

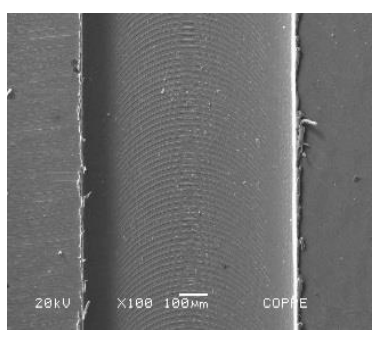

(d) Exp. 4

Figure 13. SEM of the top view and of the start of the channel for a replicate of each experiment.

In order to analyze the influence of the factors, feed per tooth and cutting speed, in the top burr height, it was made an Analysis of Variance (ANOVA). It was used the same data configuration presented in 3.1. The hypotheses tested for each parameter were:

- H0 (Null Hypothesis) - the top burr height does not vary with the parameter;

- H1 (Alternative Hypothesis) - the top burr height varies with the parameter.

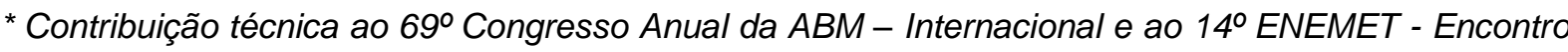
Nacional de Estudantes de Engenharia Metalúrgica, de Materiais e de Minas, 21 a 25 de julho de 2014, São Paulo, SP, Brasil.
} 
Using a significance level a of 0.05 , a critical value $F$ equal to 5.32 is found. From Table 7 it is possible to observe that the burr height is not influenced by spindle speed and feed per tooth, as $F<F_{\text {critical. }}$.

Table 7. ANOVA top burr height.

\begin{tabular}{l|c|c|c|c|c}
\hline Source & SS & Df & MS & F & Prob $>$ F \\
\hline Spindle speed & 0.881 & 1 & 0.8812 & 0.05 & 0.8242 \\
\hline Feed per tooth & 67.09 & 1 & 670.899 & 4.01 & 0.0802 \\
\hline Interaction & 44.184 & 1 & 441.842 & 2.64 & 0.1428 \\
\hline Error & 133.841 & 8 & 167.302 & & \\
\hline Total & 245.997 & 11 & & &
\end{tabular}

\subsection{Tool Wear}

The control of cutting parameters which influence on the tool life in micromilling processes is of very importance, as variations of the tool diameter and of the cutting edge wear influence on the accuracy, on the roughness and induce the formation of burrs, Takács et al. [7]; Biermann and Steiner [9]; Wu [15]. The increase of the cutting speed and feed per tooth in machining processes tends to lower the life of the cutting tool because of the higher wear.

Figure 14 shows the top view of the micromill as received $\left(\mathrm{d}_{\mathrm{s}}=0.76 \mathrm{~mm}\right)$ and after use $\left(\mathrm{de}_{\mathrm{e}}=0.71 \mathrm{~mm}\right)$. Figure 15 shows the raise of the roughness for all the first, second and third replicas of all experiments. It is possible to observe the increase of the tool wear by the increase of the $\mathrm{R}_{\mathrm{a}}$.

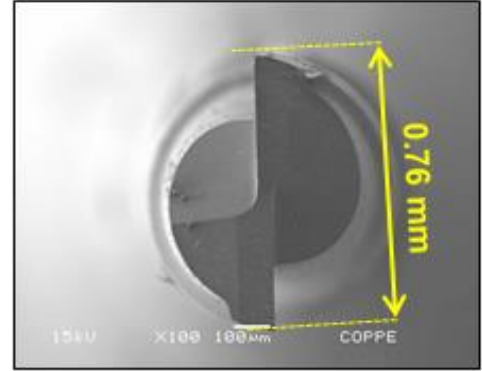

(a) Microtool as received

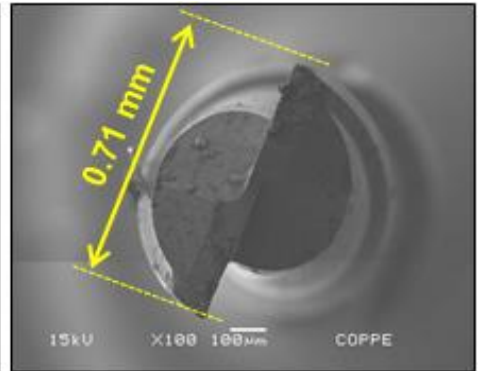

(b) Microtool after use

Figure 14. Measure of the tool diameter before and after micromilling.

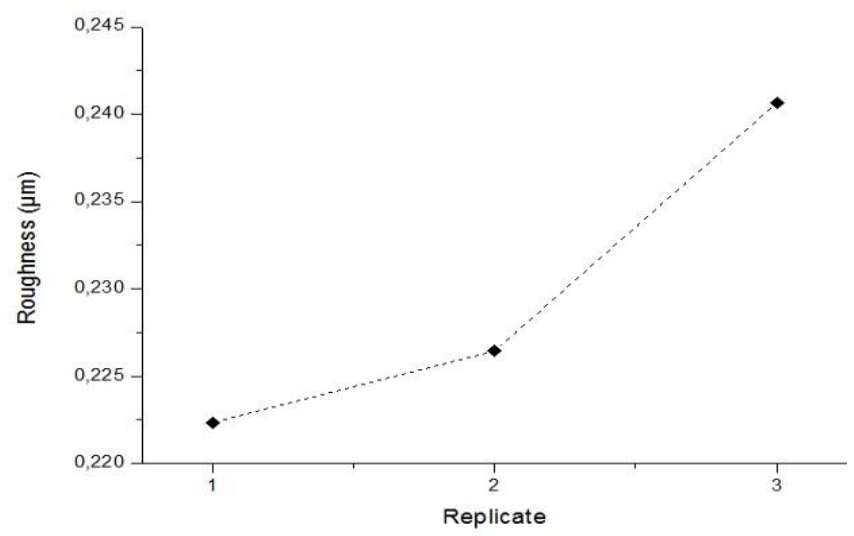

Figure 15. Variation of the roughness for the three replicates of all experiments.

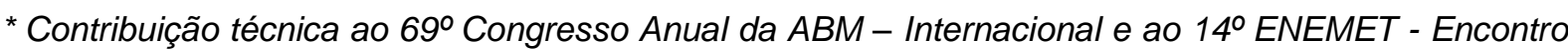
Nacional de Estudantes de Engenharia Metalúrgica, de Materiais e de Minas, 21 a 25 de julho de 2014, São Paulo, SP, Brasil.
} 


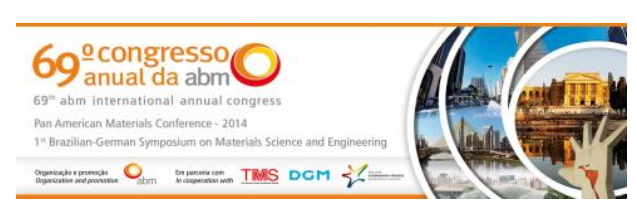

\section{CONCLUSION}

This article presented an experimental study of the micromilling of super duplex stainless steel UNS S 32750 and the influence of the cutting parameters on the surface integrity and on the tool wear.

About the surface integrity, roughness results in transversal and longitudinal direction of the channels indicated the raise of the roughness for higher values of feed per tooth, showing little or no influence of spindle speed, as presented by the ANOVA. The analysis of variance also indicated that the top burr height did not suffer any influence of the cutting parameters. Despite this, images obtained with SEM showed that burr formation was higher for lower feed per tooth.

The surface roughness increased with the cutting time, as it can be seen comparing the three replicates of all four experiments, as consequence of tool wear confirmed in microscope images. The initial diameter of the micromilling tool reduced from $0.76 \mathrm{~mm}$ to $0.71 \mathrm{~mm}$.

It is suggested for future work the use of lower feed per tooth, less than cutting edge radius, to verify the influence of the minimum chip thickness on the surface roughness, on the burr formation and on the elastic recovery of the micromilled channels.

\section{Acknoledgments}

The authors thank to: the support of the CAPES for acquiring the equipment used in this article thru Proequipment resources and for the Mechanical Engineering Department. The cutting fluid was kindly supplied by Quaker Chemical.

\section{REFERÊNCIAS}

1 Schmidt J, Tritschler H. Micro cutting of steel. 2004; 10(3):167-174.

2 Arai R. Estudo teórico-experimental do efeito da flexão da ferramenta no processo de microfresamento [Dissertação de Mestrado]. Escola de Engenharia de São Carlos: Universidade de São Paulo; 2008.

3 Aramcharoen A, Mativenga PT. Size effect and tool geometry in micromilling of tool steel. Precision Engineering. 2009; 33(4):402-407.

4 Bao WY, Tansel IN. Modeling micro-end-milling operations. Part I: analytical cutting force model. International Journal of Machine Tools and Manufacture. 2000; 40(15): 2155-2173.

5 Simoneau A, Ng E, Elbestawi MA. Chip formation during microscale cutting of a medium carbon steel. International Journal of Machine Tools and Manufacture. 2006; 46(5): 467-481.

6 Weule H, Hüntrup V, Tritschler H. Micro-Cutting of Steel to Meet New Requirements in Miniaturization. CIRP Annals - Manufacturing Technology. 2001; 50(1); 61-64.

7 Takács M, Verö B, Mészáros I. Micromilling of metallic materials. Journal of Materials Processing Technology. 2003; 138(1-3); 152-155.

8 Jin C, Kang I, Park J, Jang S, Kim J. The characteristics of cutting forces in the micromilling of AISI D2 steel. Journal of Mechanical Science and Technology. 2009; 23(10): 2823-2829.

9 Biermann D, Steiner M. Analysis of Micro Burr Formation in Austenitic Stainless Steel X5CrNi18-10. Procedia CIRP. 2012;3:97-102.

10 Bordinassi EC, Stipkovic MF, Batalha, GF. Superficial integrity analysis in a super duplex stainless steel after turning. Journal of Achievements in Materials as Manufacturing Engineering. 2006; 18(1-2)335-338.

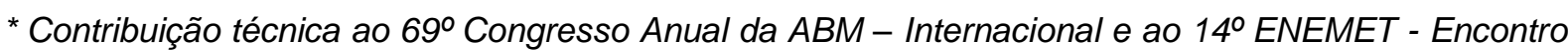
Nacional de Estudantes de Engenharia Metalúrgica, de Materiais e de Minas, 21 a 25 de julho de 2014, São Paulo, SP, Brasil.
} 
11 Fonseca MC, Barbosa MFM, Bartholo RN, Marques Jr. A, Pardal JM, Araujo AC. Estudo das tensões residuais geradas na usinagem por fresamento de amostras de aço superduplex. V Congresso Nacional de Engenharia Mecânica. 2008. SalvadorBahia.

12 Bayesteh A, Gym D, Jun MBG. 2-Dimensional Ploughing Simulation Model Development in Micro Flat End Milling. $8^{\text {th }}$ International Conference on MicroManufacturing. University of Victoria, Victoria BC, Canada. 2003:25-28.

13 Moreira SRS. Energia específica de corte e integridade superficial no microfresamento do aço ABNT 1045 [Dissertação de Mestrado]. Faculdade de Engenharia de Ilha Solteira: Universidade Estadual Paulista Júlio de Mesquita Filho; 2012.

14 Hashimura M, Hassamontr J, Dornfeld DA. Effect of In-plane Exit Angle and Rake Angles on Burr Height and Thickness in Face Milling Operation. Journal of Manufacturing Science and Engineering. 1999; 121(1):13-19.

15 Wu T. Tooling Performance in Micro Milling: Modelling, Simulation and Experimental Study [Doctor Thesis]. School of Engineering and Design: Brunel University; 2012.

* Contribuição técnica ao $69^{\circ}$ Congresso Anual da ABM - Internacional e ao 14ํㅡㄹ ENEMET - Encontro Nacional de Estudantes de Engenharia Metalúrgica, de Materiais e de Minas, 21 a 25 de julho de 2014, São Paulo, SP, Brasil. 